\title{
ARTICLE OPEN Recombinant amelogenin regulates the bioactivity of mouse cementoblasts in vitro
}

\author{
Sema S. Hakki ${ }^{1,2}$, S. Buket Bozkurt ${ }^{2}$, Emre Türkay ${ }^{3}$, Michel Dard ${ }^{4}$, Nuhan Purali ${ }^{5}$ and Werner Götz ${ }^{3}$
}

Amelogenin (AMG) is a cell adhesion molecule that has an important role in the mineralization of enamel and regulates events during dental development and root formation. The purpose of the present study was to investigate the effects of recombinant human AMG (rhAMG) on mineralized tissue-associated genes in cementoblasts. Immortalized mouse cementoblasts (OCCM-30) were treated with different concentrations $\left(0.1,1,10,100,1000,10,000,100,000 \mathrm{ng} \cdot \mathrm{mL}^{-1}\right.$ ) of recombinant human AMG (rhAMG) and analyzed for proliferation, mineralization and mRNA expression of bone sialoprotein (BSP), osteocalcin (OCN), collagen type I $(\mathrm{COL} \mathrm{I})$, osteopontin (OPN), runt-related transcription factor 2 (Runx2), cementum attachment protein (CAP), and alkaline phosphatase (ALP) genes using quantitative RT-PCR. The dose response of rhAMG was evaluated using a real-time cell analyzer. Total RNA was isolated on day 3, and cell mineralization was assessed using von Kossa staining on day 8. COL I, OPN and lysosomalassociated membrane protein-1 (LAMP-1), which is a cell surface binding site for amelogenin, were evaluated using immunocytochemistry. F-actin bundles were imaged using confocal microscopy. rhAMG at a concentration of $100,000 \mathrm{ng} \cdot \mathrm{mL}^{-1}$ increased cell proliferation after $72 \mathrm{~h}$ compared to the other concentrations and the untreated control group. rhAMG (100,000 ng . $\mathrm{mL}^{-1}$ ) upregulated BSP and OCN mRNA expression levels eightfold and fivefold, respectively. rhAMG at a concentration of $100,000 \mathrm{ng} \cdot \mathrm{mL}^{-1}$ remarkably enhanced LAMP-1 staining in cementoblasts. Increased numbers of mineralized nodules were observed at concentrations of 10,000 and $100,000 \mathrm{ng} \cdot \mathrm{mL}^{-1}$ rhAMG. The present data suggest that rhAMG is a potent regulator of gene expression in cementoblasts and support the potential application of rhAMG in therapies aimed at fast regeneration of damaged periodontal tissue.

International Journal of Oral Science (2018)10:15 https://doi.org/10.1038/s41368-018-0010-5

\section{INTRODUCTION}

Enamel matrix derivative (EMD) is a group of enamel matrix proteins that are derived from Hertwig's root sheath of developing porcine teeth. In vitro studies have shown positive effects of EMD on the proliferation of periodontal ligament (PDL) cells, gingival fibroblasts, follicle cells, and cementoblasts. ${ }^{1-7}$ Commercially available EMD suspended in a hydrogel (Emdogain ${ }^{\circledR}$, Institut Straumann AG, Basel, Switzerland) is used for regenerative therapy around natural teeth. This formulation is a specific approach for enhancing periodontal regeneration. Clinical studies have indicated that EMD treatment positively influences periodontal wound healing and regeneration in humans. ${ }^{8}$ Most human clinical trials and case series of Emdogain application have demonstrated significant improvements in probing depth radiographic evidence of bone augmentation and cementum regeneration alone or in combination with bone grafts. ${ }^{7,9-14}$ Histological results from animal and human studies have confirmed these positive effects. EMD has been shown to be osteogenic and cementogenic, ${ }^{15,16}$ and it exerts a direct effect on osteoblasts via the enhancement of mineralization activity. ${ }^{17}$ Additionally it is known that EMD can interact with various other cells, including osteoblasts and dental stem cells. ${ }^{4,18-23}$
EMD is a hierarchical complex of proteins, and the identity of the components responsible for its biological effects is not known. Amelogenin (AMG) is an enamel matrix protein that is secreted by ameloblasts. AMG constitutes $\sim 90 \%$ of the extracellular matrix of enamel, and it is the primary component of EMD. AMG has an important role in the mineralization of enamel and regulates mineralized tissue-associated factors during dental development, including root formation. ${ }^{24,25}$ AMG is also a signaling molecule in epithelial-mesenchymal interactions during odontogenesis and root formation. ${ }^{1}$ AMGs were initially considered tissue specific and exclusively expressed by the enamel-producing ameloblast cells. However, various isoforms have been found in the dentin matrix and associated odontoblasts. Recent reports suggest the expression of AMG in the periodontal ligament and Hertwig's epithelial root sheath of the developing tooth attachment apparatus and other tissues. ${ }^{26}$ AMG polypeptides have been associated with cell signaling and may exhibit osteogenic potential. Tompkins et al. ${ }^{27}$ characterized an AMG cell surface receptor in the mouse, lysosome associated membrane protein-1 (LAMP-1), which is also found at cell surfaces, where it acts as a binding protein that may be involved in the interaction between cells and AMG. Exogenously added AMG is taken up by cells into LAMP-1-positive vesicles. ${ }^{28}$

\footnotetext{
${ }^{1}$ Department of Periodontology, Faculty of Dentistry, Selçuk University, 42079 Konya, Turkey; ${ }^{2}$ Research Center of Dental Faculty, Selçuk University, Konya, Turkey; ${ }^{3}$ Department of Orthodontics, Oral Biology Laboratory, Faculty of Dentistry, University of Bonn, Bonn, Germany; ${ }^{4}$ Department of Periodontology and Implant Dentistry, College of Dentistry, New York University, New York, NY, USA and ${ }^{5}$ Department of Biophysics, Faculty of Medicine, Hacettepe University, Ankara, Turkey Correspondence: Sema S. Hakki (sshakki@yahoo.com, sshakki@selcuk.edu.tr)
} 
Recent studies revealed that AMG-derived peptides exhibited potential as a useful tool for the treatment of periodontal and orthopedic diseases. ${ }^{4}$ Gungormus et al. used AMG-derived peptide 5 (ADP5) as a biomineralizing protein to engineer mineral formation and promote periodontal tissue regeneration. These authors suggested that the cementomimetic (e.g., cementum-like) layer formed by ADP5 may be used clinically to repair diseased root surfaces. AMG and its peptides contribute to the cell-based regeneration of periodontal tissues. Therefore, an understanding of the AMG-mediated signaling factors that regulate cementogenesis is critical. $^{29}$

EMD and its components, e.g., AMG, are obtained via extraction from the crude enamel matrix, but recent studies attempted recombinant technology. Simmer et al. ${ }^{30}$ first described recombinant AMG produced in E. coli using a splice variant of murine AMG. Deutsch et al. ${ }^{31}$ and Taylor et al. $^{32}$ described the expression of a recombinant human AMG protein in a eukaryotic baculovirus system for the first time. Their in vivo regeneration studies revealed that the recombinant AMG protein substantially increased the regeneration of periodontal tissues after induced periodontitis. ${ }^{33} \mathrm{Li}$ et al. $^{34}$ developed a recombinant AMG, rh174, using an $E$. coli system. Svensson et al. ${ }^{35}$ successfully developed another process for the purification of human recombinant AMG in E. coli based on the solubility properties of AMG and examined its effects on osteoblasts in vitro.A recent clinical study suggested that rhAMG enhanced apex formation and induced connective tissue regeneration. ${ }^{36}$ The purpose of the present study was to investigate the effects of the rhAMG developed by Svensson et al. ${ }^{35}$ on the proliferation, mineralization and expression of mineralized tissueassociated genes and the cementum-specific marker cementum attachment protein (CAP) in mouse cementoblasts.

\section{RESULTS}

Real-time cell analysis results

There were no significant differences among rhAMG concentrations until $72 \mathrm{~h}$, when an apparent increase was noted in the $100,000 \mathrm{ng} \cdot \mathrm{mL}^{-1}$ group (Fig. 1). Only $100,000 \mathrm{ng} \cdot \mathrm{mL}^{-1} \mathrm{rhAMG}-$ stimulated OCCM-30 cell proliferation, and the other concentrations of AMG exhibited no effect.

Effects of rhAMG on the mRNA expression levels of mineralized tissue-related genes in OCCM-30 cells

As shown in Fig. 2, the mRNA expression levels of BSP in OCCM-30 cells was upregulated significantly $(P<0.01)$ after rhAMG treatment. The most pronounced upregulation (approximately eightfold) was observed in the $100,000 \mathrm{ng} \cdot \mathrm{mL}^{-1} \mathrm{rhAMG}$ group. RhAMGstimulated runt-related transcription factor 2 (Runx2) mRNA levels in a dose-dependent manner. The highest rhAMG concentrations $\left(10,000\right.$ and $\left.100,000 \mathrm{ng} \cdot \mathrm{mL}^{-1}\right)$ upregulated the OPN transcript. RhAMG concentrations of $0.1-10,000 \mathrm{ng} \cdot \mathrm{mL}^{-1}$ did not alter OCN mRNA expression, but $100,000 \mathrm{ng} \cdot \mathrm{mL}^{-1}$ rhAMG stimulated at least a threefold increase in OCN transcription in OCCM-30 cells. COL I mRNA expression was stimulated by all concentrations of rhAMG. The most significant increase in COL I mRNA expression (approximately fivefold) was observed after $100,000 \mathrm{ng} \cdot \mathrm{mL}^{-1}$ rhAMG treatment. ALP and CAP mRNA expression was upregulated at $1 \mathrm{ng} \cdot \mathrm{mL}^{-1} \mathrm{rhAMG}(P<0.05)$, and a more pronounced upregulation was observed at higher concentrations $(P<0.01)$

\section{Mineralization}

All concentrations of rhAMG resulted in increased biomineralization (Fig. 3). This induction was more apparent in groups treated with 10,000 and $100,000 \mathrm{ng} \cdot \mathrm{mL}^{-1}$ rhAMG than in the untreated groups.

Immunocytochemistry

Osteopontin. A subpopulation of non-stimulated cementoblasts exhibited weak to moderate cytoplasmic immunostaining, and other cells were negative (Fig. 4a). The intensity of staining increased in cells stimulated with $10 \mathrm{ng} \cdot \mathrm{mL}^{-1} \mathrm{rhAMG}$, and higher concentrations exhibited a similar pattern for all concentrations tested.

Collagen type $I$. Few non-stimulated cells exhibited weak cytoplasmic immunostaining, and the remaining cells were not stained. Moderate staining in an increased number of cells was observed in cultures stimulated with $1-1000 \mathrm{ng} \cdot \mathrm{mL}^{-1}$ (Fig. 4b), but higher concentrations produced an immunostaining pattern similar to that of non-stimulated cells.

LAMP-1. Non-stimulated cells and cells stimulated with 1, 10, 100, and 1000 ng rhAMG revealed no immunostaining (Fig. 4c). Few cells exhibited granular cytoplasmic immunostaining after stimulation with $10,000 \mathrm{ng}$, and nearly all cells were stained in the $100,000 \mathrm{ng} \cdot \mathrm{mL}^{-1}$ rhAMG group.

\section{Immunofluorescence}

The fluorescence intensity of f-actin-labeled cementoblasts was slightly stronger with 100,000 rhAMG than with the control group (Fig. 5). rhAMG concentrations $<100 \mu \mathrm{g} \cdot \mathrm{mL}^{-1}$ induced no detectable change in fluorescence intensity. However, the fluorescence intensity was greater in cells incubated in $100 \mu \mathrm{g} \cdot \mathrm{mL}^{-1}$ rhAMG. Intensity histograms shifted towards larger intensity amplitudes in rhAMG-treated cells than in the control group. No differences between experimental groups were observed for $\beta 1$ integrinlabeled images.

\section{DISCUSSION}

Cementoblasts and their precursors have important roles in periodontal repair and regeneration via the formation of new cementum after proliferation and migration to the root surface. ${ }^{37}$ The OCCM-30 cells used in this study are immortalized mouse cementoblasts that are well characterized and widely used for cementoblast stimulation in vitro to investigate cementum regeneration. ${ }^{38}$ In this study, these cells were stimulated by a newly developed rhAMG with unknown biological functions on periodontium cells. ${ }^{35}$ We demonstrated that higher concentrations (e.g., $100,000 \mathrm{ng} \cdot \mathrm{mL}^{-1}$ ) of rhAMGstimulated cementoblast proliferation and mineralization and upregulated important osteogenic factors, such as ALP, BSP, Runx2, OCN, type I collagen, and OPN and the cementum-specific marker CAP.

RhAMG increased OCCM-30 cell proliferation. Murine cementoblasts exhibited enhanced cell proliferation after EMD exposure, ${ }^{39,40}$ but stimulation with a full-length murine AMG protein, an N-terminal AMG peptide or a leucine-rich AMP peptide (LRAP) produced no effects. ${ }^{35,40,41}$ Therefore, the rhAMG used in the present study may increase cementoblast proliferation. Induction of the proliferation of human cementoblast cell lines was demonstrated previously after treatment with another type of rhAMG. ${ }^{42,43}$ However, lower AMG concentrations were sufficient in these studies. Obviously, higher concentrations of AMG are required to stimulate proliferation in mouse cementoblasts. Previous studies failed to promote proliferation in mouse cementoblasts after treatment with concentrations up to $1000 \mathrm{ng} \cdot \mathrm{mL}^{-1} \cdot{ }^{24}$ Swanson et al. ${ }^{24}$ used $0.1,1$, and $10 \mu \mathrm{g} \cdot \mathrm{mL}^{-1}$ tyrosine-rich amelogenin peptide (TRAP) on the same cementoblasts used in our study, and they observed no significant difference in cell proliferation among these three TRAP concentrations. Higher TRAP concentrations may have produced an effect on the cells. These cells are immortalized mouse cells, which may behave differently from primary human or mouse cells. The mitotic activity of OCCM-30 cells is higher than that of primary cells, and these cells may require higher AMG concentrations to induce cell functions. ${ }^{24}$ 

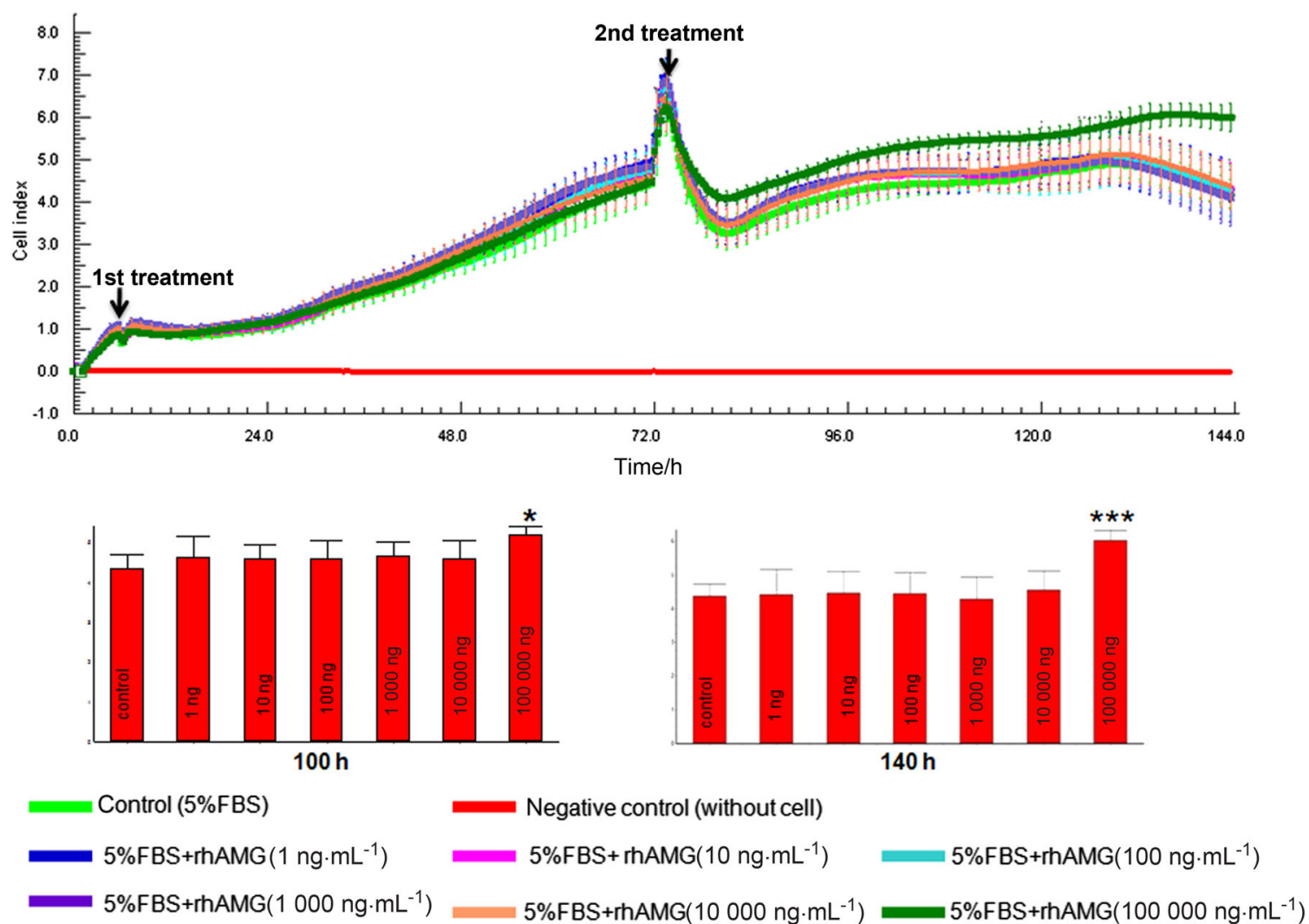

Fig. 1 Cell index graph of OCCM-30 cells $(n: 3)$ treated with different concentrations of rhAMG using RTCA-SP. Cells treated with 100,000 ng . $\mathrm{mL}^{-1}$ exhibited a higher cell proliferation rate than other concentrations and the control group. Proliferation experiments were repeated twice. Bottom graphs show the difference between the concentrations at 100 and $140 \mathrm{~h}$. rhAMG, recombinant human amelogenin

The rhAMG used in this study promoted mineralization in OCCM-30 cells as demonstrated by the mineralization assay. This result contrasts the stimulation of these cells with EMD, full-length murine AMG, LRAP and a tyrosine-rich AMG peptide, which produced no effects. ${ }^{35,39-41}$ Viswanathan et al. ${ }^{40}$ demonstrated decreased OCN and BSP mRNA transcripts and mineral nodule formation in vitro following treatment of mouse cementoblasts with a high dose $\left(10 \mu \mathrm{g} \cdot \mathrm{mL}^{-1}\right)$ of full-length murine AMG protein $(\mathrm{rp}(\mathrm{H}) \mathrm{M} 180)$. They observed similar cell proliferation in AMGtreated cells as the control. The present study revealed increased proliferation of mouse cementoblasts after treatment with a higher dose $\left(100 \mu \mathrm{g} \cdot \mathrm{mL}^{-1}\right)$ that had not been used by Visvanathan et al. ${ }^{40}$ We also did not observe any significant changes at the other concentrations. In contrast, we observed increased ALP, $\mathrm{OCN}$, and BSP expression levels and stronger biomineralization in cementoblasts. These differences may be explained by the use of murine AMG for stimulation in the Visvanathan study. ${ }^{40}$

Tanimoto et al. $^{44}$ recently demonstrated that treatment of human cementoblasts (HCEMs) with recombinant human fulllength AMG (rh174) upregulated ALP, OCN, and BSP mRNA levels. OCN and BSP protein levels, ALP activity and calcium deposition resulted in enhanced mineralization. These investigators used 0 to $1000 \mathrm{ng} \cdot \mathrm{mL}^{-1}$ rh174. Similar results using a concentration of $1000 \mathrm{ng} \cdot \mathrm{mL}^{-1}$ in our study demonstrated that murine cementoblasts required higher concentrations to achieve these effects.

Interestingly, similar results were observed when the same cell type was treated with LRAP or TRAP (tyrosine-rich amelogenin peptide, which is a degradation product of full-length AMG). ${ }^{35,41}$ The splice product LRAP has been shown to enhance the expression of Runx2, which is the most important factor for osteogenic differentiation. ${ }^{45}$ LRAP treatment induced a significant increase in mineral matrix formation and BSP in wild-type and AMG-null mouse embryonic stem cells. ${ }^{46}$ Amin et al. ${ }^{17}$ recently demonstrated that TRAP suppressed the formation of bone-like mineralized nodules, and LRAP upregulated osteogenic differentiation in bone precursor cells. These studies demonstrated that AMG and its peptides modulated the expression of mineralized tissue-associated genes and mineralization. ${ }^{4}$ The effects on mineralization are consistent with previous studies, which demonstrated the effects of EMD and AMG on osteoblasts, osteoblast-like cells, and stem cells. ${ }^{47-52}$ These data suggest a close relationship among cementoblasts, osteoblasts, osteoblast precursor cells, and mesenchymal stem cells. ${ }^{37}$ In contrast, PDL fibroblasts, which exhibit an osteogenic phenotype, did not upregulate mineralization markers after rhAMG treatment in one study. ${ }^{44}$

The expression data were only partially mirrored on the protein level in our study. OPN immunostaining also increased after stimulation with higher rhAMG concentrations, and type I collagen immunostaining was stronger only after stimulation with moderate concentrations. Tanimoto et al. ${ }^{44}$ demonstrated that recombinant AMG rh174 did not alter protein levels of OCN and BSP in human cementoblasts. No clear correlations between OPN and COLI expression levels and immunostaining intensity were observed. However, the control mechanisms for gene expression and translation in cementoblasts are not known. Epigenetic mechanisms driven by microRNAs may control expression in cementoblasts similarly to osteoblasts ${ }^{53}$ and influence protein secretion. The lack of evaluation of mineralized tissue/cementumassociated protein (BSP and OCN) levels was a limitation of this study. Quantification of protein levels would substantially improve our data and confirm the changes in mRNA expression in the OCCM-30 cells treated with rhAMG.

RhAMG-induced CAP upregulation in mouse cementoblasts may be interpreted in the circumstance of wound healing and cementum repair and regeneration because CAP has a regulatory 

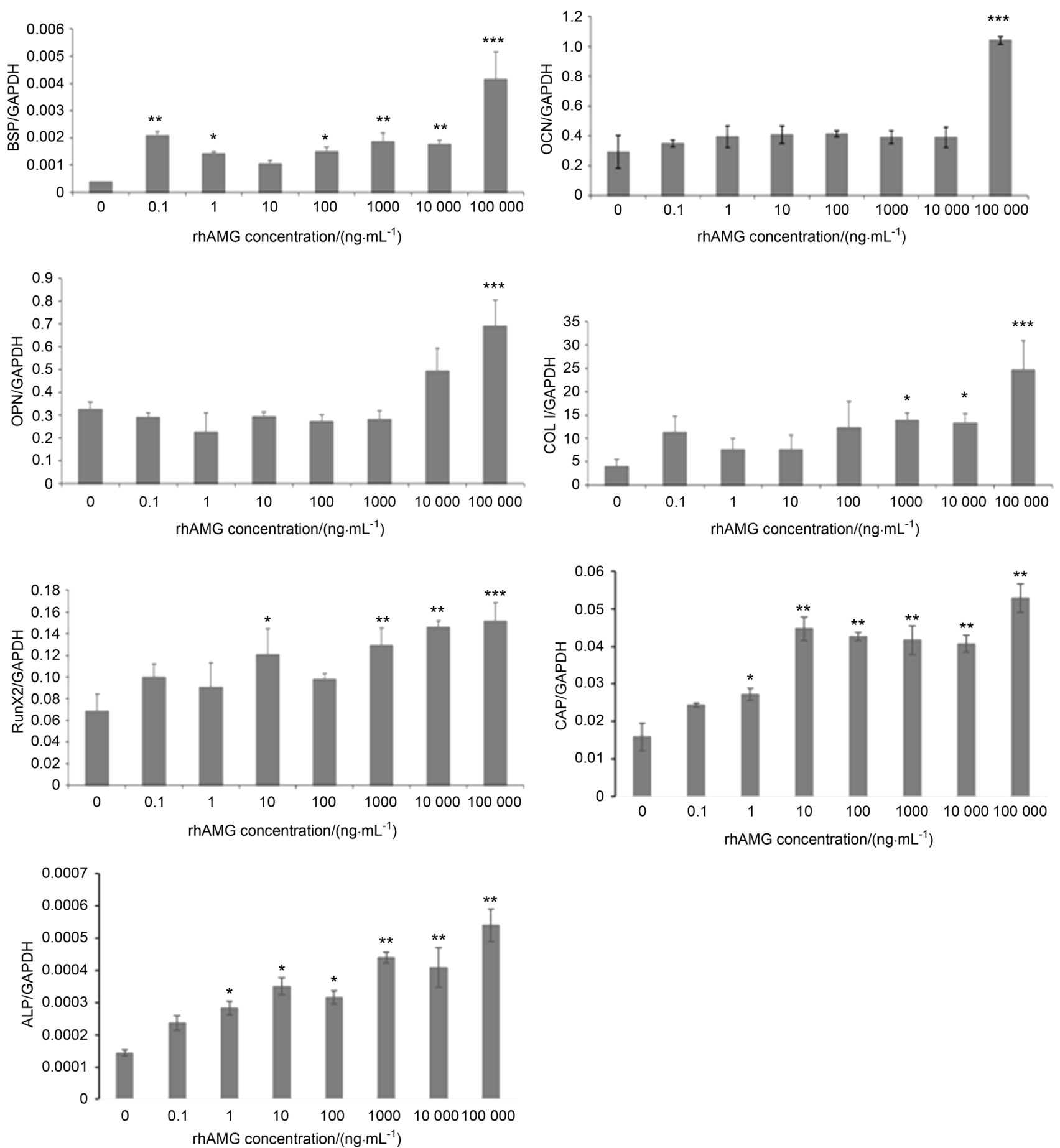

Fig. 2 mRNA expression of mineralized tissue-associated genes (BSP, OCN, OPN, COL1, Runx2, CAP, and ALP) in OCCM-30 cells using quantitative RT-PCR. (Target genes were normalized to housekeeping genes). Experiments were repeated three times. ${ }^{* * *} P<0.001,{ }^{* *} P<0.01$, ${ }^{*} P<0.05$. rhAMG, recombinant human amelogenin

role in cementum formation and the promotion of attachment of PDL cells, gingival fibroblasts, and endothelial cells. CAP is also involved in the promotion of the differentiation of cementoblast precursors. $^{54}$

Our results demonstrated for the first time that OCCM-30 cells express LAMP-1, which is a putative AMG receptor, after rhAMG stimulation. The results of our immunohistochemical experiments demonstrated that stimulated LAMP-1 staining was observed in the $100,000 \mathrm{ng} \cdot \mathrm{mL}^{-1}$ rhAMG group. LAMP-1 may be a cell surface receptor for the specific amelogenin isoform leucine-rich amelogenin peptide. Zhang et al. ${ }^{55}$ used full-length recombinant mouse amelogenin, $\mathrm{rp}(\mathrm{H}) \mathrm{M} 180$, on murine dental follicle cells and cementoblasts (OCCM-30) and observed maximum surface binding at $50 \mu \mathrm{g} \cdot \mathrm{mL}^{-1}$ of $\mathrm{rp}(\mathrm{H}) \mathrm{M} 180$. Their data suggested that LAMP1 is a cell surface binding site for amelogenin on dental follicle cells and cementoblasts. Tanimoto et al. ${ }^{44}$ also suggested that LAMP-1 signaling was responsible for the effects of rh174 AMG on the mineralization of human cementoblasts. However, Kunimatsu et al. ${ }^{43}$ demonstrated that the cell surface antigen CD63 interacted with rhAMG. 

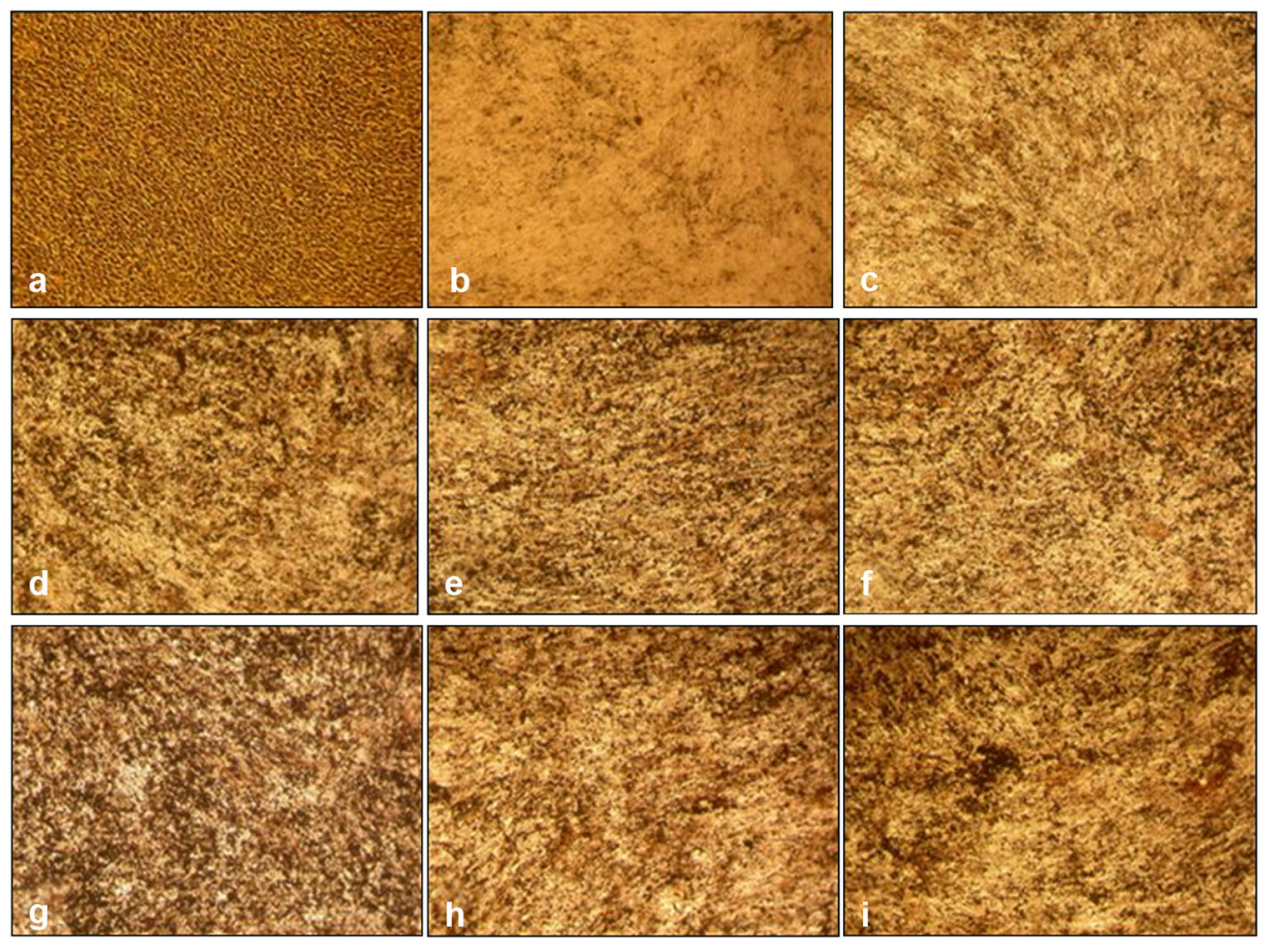

Fig. 3 Biomineralization of OCCM-30 cells. Osteogenic differentiation was indicated by the formation of calcified nodules with von Kossa staining on day 8 . a negative control (without mineralization media), b positive control [with mineralization media: ascorbic acid (AA, $50 \mu \mathrm{g} /$ $\mathrm{ml}$ ) and $\beta$-glycerophosphate (BGP, $10 \mathrm{mM})]$, c $0.1 \mathrm{ng} \cdot \mathrm{mL}^{-1}, \mathbf{d ~} 1 \mathrm{ng} \cdot \mathrm{mL}^{-1}$, e $10 \mathrm{ng} \cdot \mathrm{mL}^{-1}, \mathbf{f} 100 \mathrm{ng} \cdot \mathrm{mL}^{-1}, \mathbf{g} 1000 \mathrm{ng} \cdot \mathrm{mL}^{-1}, \mathbf{h ~} 10.000 \mathrm{ng}^{1} \mathrm{~mL}^{-1}$, i $100.000 \mathrm{ng} \cdot \mathrm{mL}^{-1}$

The present results revealed no effects on integrin immunostaining after rhAMG stimulation. This observation suggests that rhAMG treatment does not influence cell adhesion at the concentrations used in this study. This result contrasts observations in human dermal fibroblasts in which AMG increased the binding of these cells via several integrins. ${ }^{56}$ Only weak effects were observed for actin immunostaining, which suggests a weak influence on the migration of OCCM-30 cells. In contrast, EMD induced lymphocyte migration in a dose-dependent manner. ${ }^{57}$ Figure 5 shows that the fluorescence intensity increased in the presence of $100 \mu \mathrm{g} \cdot \mathrm{mL}^{-1} \mathrm{rhAMG}$. Histogram analyses indicated greater intensities at a higher frequency in the $100 \mu \mathrm{g} \cdot \mathrm{mL}^{-1}$ rhAMG-treated group. Therefore, we suggest that rhAMG $(100 \mu \mathrm{g}$. $\mathrm{mL}^{-1}$ ) treatment induced an increase in the f-actin content of cementoblast cells. Notably, the cells in our study were incubated, labeled and imaged under identical conditions, and normalized histogram analyses yielded a reliable quantitative parameter that was independent of the number of cells in the imaged frame. The fluorescent labeling and confocal microscopy results support the PCR and proliferation experiments.

Defining the roles of different types of AMG (i.e., murine, human, recombinant) and its peptides in modulating the activity of cementoblasts or progenitor cells in vitro will provide critical information for the design of regenerative periodontal therapies. Further comparative studies will reveal whether the rhAMG examined in this study is superior to natural EMD, AMG or its peptides in cementoblasts. Notably, rhAMG may be used as a fusion partner between other proteins that may be important for regeneration, e.g., PTH or BMPs. ${ }^{58,59}$ Functionalized rhAMG may also have a role in tissue engineering in the future. ${ }^{60}$

\section{MATERIALS AND METHODS}

An immortalized cementoblast cell line (OCCM-30) was used for these studies. The methods for isolating and immortalizing these cells have been published previously. ${ }^{38,61}$ Cells were kindly provided by Dr. Martha J. Somerman (NIDCR, NIH, USA). rhAMG was kindly donated by Johan Svensson (Department of Pure and Applied Biochemistry, Center for Chemistry and Chemical Engineering, Lund University, Lund, Sweden)

Preparation of recombinant AMG

Briefly, a gene encoding the X-chromosomal human 175 amino acid amelogenin (NCBI accession number AAA51717, excluding the 16 amino acid $\mathrm{N}$-terminal signal peptide) was synthesized using PCR. Nine oligonucleotides $\sim 80 \mathrm{bp}$ long with $\sim 20 \mathrm{bp}$ complementary ends were used to construct the gene, which was codon optimized for the $E$. coli expression strain BL21 (DE3). The oligonucleotides were mixed and assembled using PfuUltra Hotstart DNA polymerase (Stratagene). The assembled amelogenin gene was amplified using PCR with flanking primers and the assembly mixture as templates. The gene was subsequently cloned into a cloning vector and sequenced. Point mutations were corrected using a QuickChange Site-Directed Mutagenesis Kit (Stratagene). The gene was inserted between the Ndel and BamHI sites in the expression vector pET11a (Novagen). Purification of the prokaryotic cell suspension was performed, and the supernatant containing the soluble fraction of amelogenin was analyzed by SDS-PAGE, HPLC, and MS. ${ }^{35,58}$

\section{Cell culture}

Cells were allowed to adhere for $24 \mathrm{~h}$ in Dulbecco's modified Eagle's medium (DMEM) with $10 \%$ foetal bovine serum (FBS). The medium was changed to $\mathrm{DMEM}^{++}$with $5 \%$ FBS containing different concentrations of AMG. The cells used in these experiments were between passages 19 and 21 . Experiments were performed twice in triplicate for each experiment for RNA isolation and three times in triplicate for mineralization. 
a

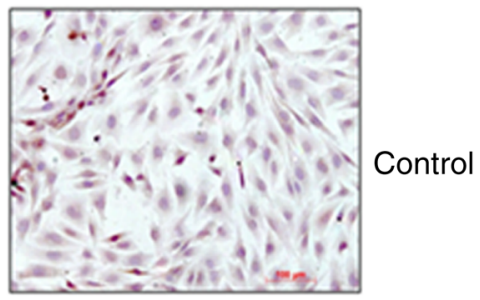

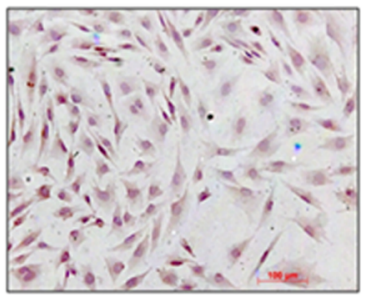

$1 \mathrm{ng} \cdot \mathrm{mL}^{-1} \mathrm{rhAmG}$

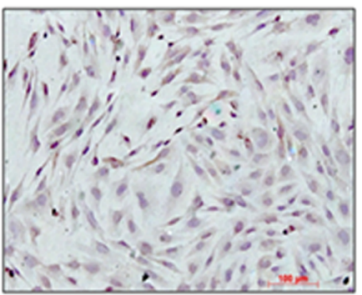

$1000 \mathrm{ng} \cdot \mathrm{mL}^{-1} \mathrm{rhAmG}$

b
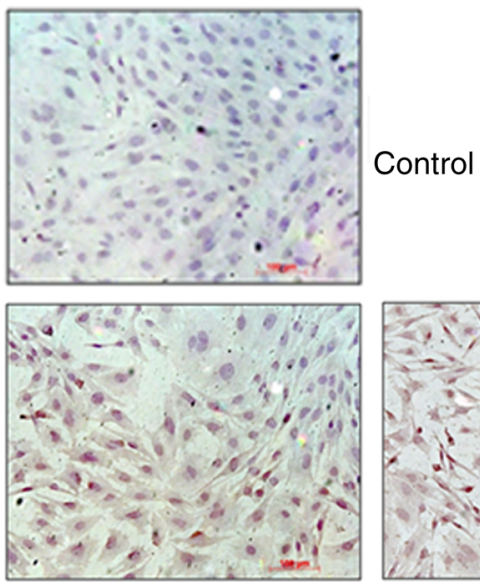

$1 \mathrm{ng} \cdot \mathrm{mL}^{-1} \mathrm{rhAmG}$

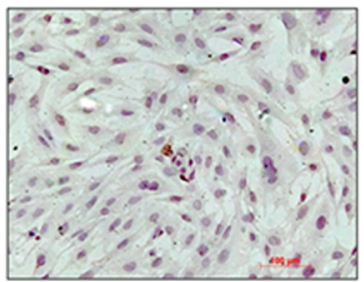

$10000 \mathrm{ng} \cdot \mathrm{mL}^{-1} \mathrm{rhAmG}$

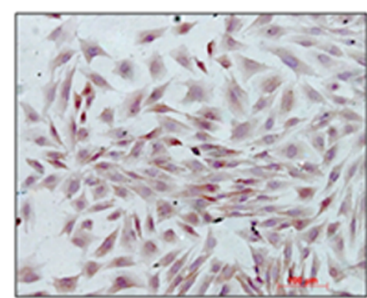

$10 \mathrm{ng} \cdot \mathrm{mL}^{-1} \mathrm{rhAmG}$

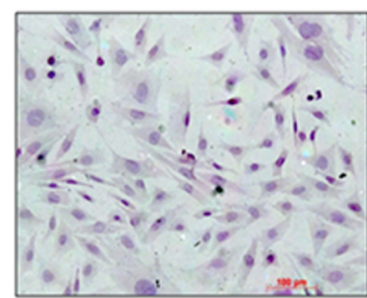

$10000 \mathrm{ng} \cdot \mathrm{mL}^{-1} \mathrm{rhAmG}$

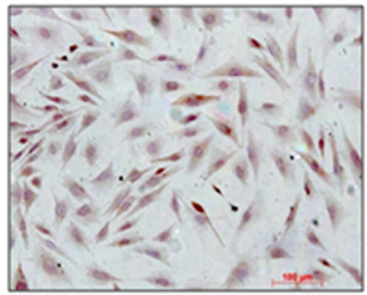

$100 \mathrm{ng} \cdot \mathrm{mL}^{-1} \mathrm{rhAmG}$

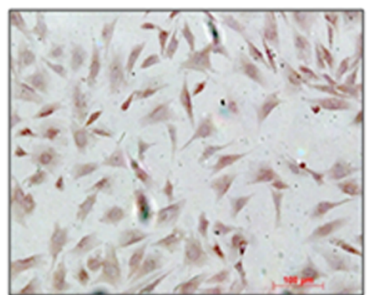

$100000 \mathrm{ng} \cdot \mathrm{mL}^{-1} \mathrm{rhAmG}$

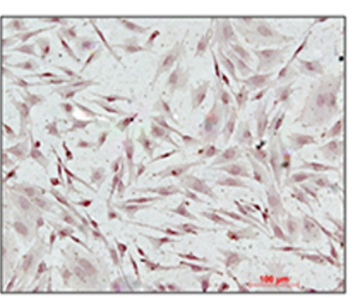

$10 \mathrm{ng} \cdot \mathrm{mL}^{-1} \mathrm{rhAmG}$

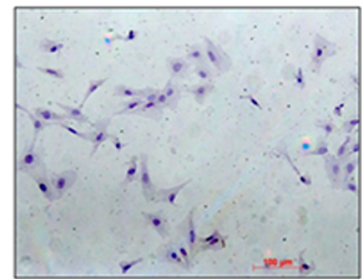

$100000 \mathrm{ng} \cdot \mathrm{mL}^{-1} \mathrm{rhAmG}$

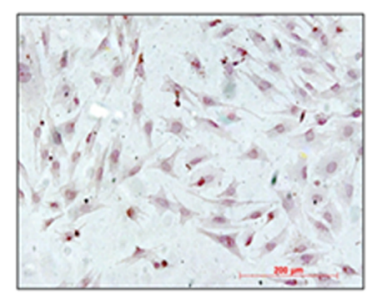

$100 \mathrm{ng} \cdot \mathrm{mL}^{-1} \mathrm{rhAmG}$

Fig. 4 Effects of different rhAMG concentrations on a OPN, b COL I, and c LAMP-1 immunostaining of OCCM-30 cells; DAB, $\times 10$

rhAMG stimulation and real-time cell analysis

OCCM-30 cells were treated with DMEM containing 5\% FBS and different concentrations of rhAMG $(0.1,1,10,100,1000,10,000$, and $\left.100,000 \mathrm{ng} \cdot \mathrm{mL}^{-1}\right)$. Five percent FBS was used as control. OCCM-30 cell proliferation was investigated using real-time cell analysis in an RTAC analyzer (RT-CES; xCELLigence, CEA Biosciences, Inc., San Diego, CA, USA). Real-time and continuous monitoring allows label-free assessment of cell proliferation, viability, and cytotoxicity, and reveals the physiological state of the cells. Cells attached to the electrode sensor surfaces act as 
C
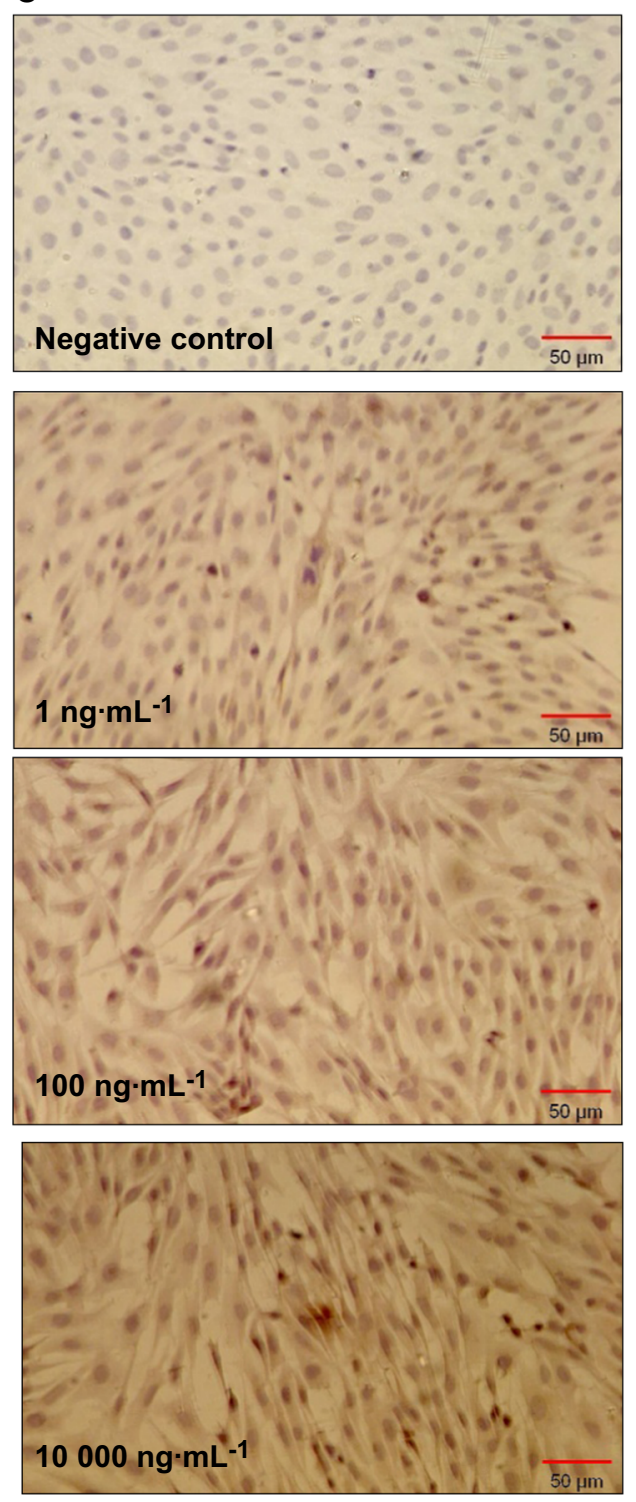
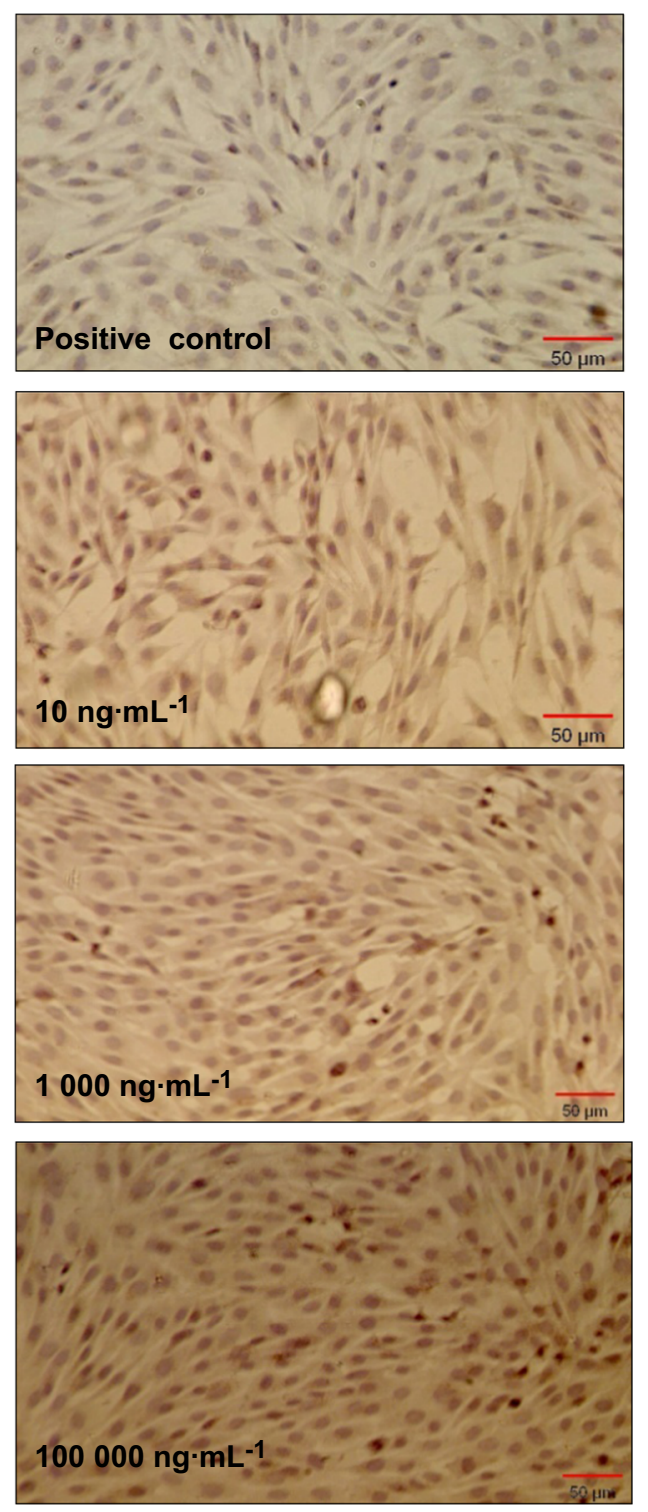

Fig. 4 Continued

insulators and thereby alter the local ion environment at the electrode-solution interface, which increases impedance. Therefore, the increased numbers of cells growing on the electrodes increases electrode impedance. Cell suspensions $(200 \mu \mathrm{L})$ were seeded into the wells (5000 cells/well) of an E-plate 96 (ACEA Biosciences), and OCCM-30 cells were monitored every 15 min for $144 \mathrm{~h}$.

\section{RNA isolation}

Cells were allowed to adhere for $24 \mathrm{~h}$ in DMEM with $10 \% \mathrm{FBS}$, and media were changed to DMEM with $5 \%$ FBS containing different concentrations of rhAMG. To determine gene expression, OCCM-30 cells were plated in $60-\mathrm{mm}$ cell culture dishes (Corning, New York, USA) at $5 \times 10^{4}$ cells $/ \mathrm{cm}^{2}$ and treated after $24 \mathrm{~h}$ as follows: (1) $5 \%$ FBS (as control), (2) $5 \% \mathrm{FBS}+$ $0.1 \mathrm{ng} \cdot \mathrm{mL}^{-1} \mathrm{rhAMG}$, (3) $5 \% \mathrm{FBS}+1 \mathrm{ng} \cdot \mathrm{mL}^{-1} \mathrm{rhAMG}$, (4) $5 \% \mathrm{FBS}+$ $10 \mathrm{ng} \cdot \mathrm{mL}^{-1} \mathrm{rhAMG}$, (5) $5 \% \mathrm{FBS}+100 \mathrm{ng} \cdot \mathrm{mL}^{-1} \mathrm{rhAMG}$, (6) $5 \% \mathrm{FBS}$ $+1000 \mathrm{ng} \cdot \mathrm{mL}^{-1} \mathrm{rhAMG}$, (7) $5 \% \mathrm{FBS}+10,000 \mathrm{ng} \cdot \mathrm{mL}^{-1} \mathrm{rhAMG}$, and (8) $5 \% \mathrm{FBS}+100,000 \mathrm{ng} \cdot \mathrm{mL}^{-1} \mathrm{rhAMG}$. Total RNA was isolated $72 \mathrm{~h}$ after treatment using a monophasic solution of phenol and guanidine isothiocyanate (InVitrogen, Camarillo, CA, USA). RNA concentrations were quantified at $260 \mathrm{~nm}$ using a spectrophotometer (Nanodrop, Wilmington, DE, USA), and RNA samples were stored at $-80^{\circ} \mathrm{C}$.

CDNA synthesis and real-time quantitative RT-PCR

For real-time RT-PCR analysis, CDNA was synthesized from $1.0 \mu \mathrm{g}$ of total RNA using a cDNA synthesis kit (High Capacity RNA-tocDNA kit, Applied Biosystems, Foster City, Carlsbad, California, USA). A volume of $1.0 \mu \mathrm{L}$ of the resulting CDNA product was used per $25 \mu \mathrm{L}$ final reaction volume in a thermal cycler (Stratagene MX3000P, La Jolla, California, USA). PCR was performed using a Brilliant SYBR Green QPCR Master Mix kit (Stratagene, La Jolla, California, USA) in a total volume of $25 \mu \mathrm{L}$. Primers were designed using DNA-Star design software. Table 1 lists the sequences. A BLAST search of GenBank was performed on the primer sequences to ensure specificity. GAPDH served as a housekeeping/reference gene for normalization. The amplification profiles of OCN, Runx2, COL I, and GAPDH used for the Stratagene MX3000P were 94/180; $94 / 45,54 / 45,95 / 60,55 / 30$, and $95 / 30$ [temperature $\left({ }^{\circ} \mathrm{C}\right) /$ time $(\mathrm{s})$ ], 

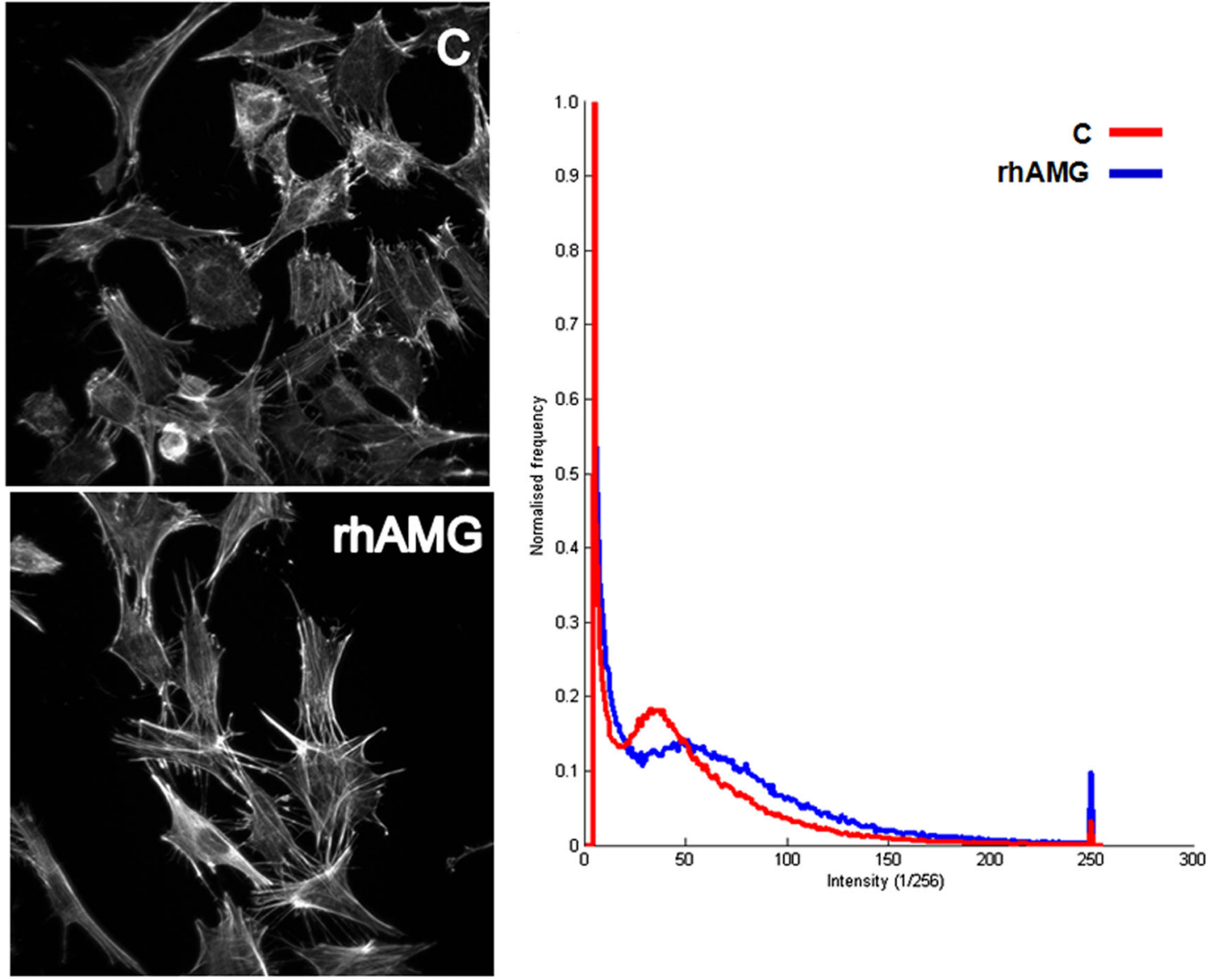

Fig. 5 Effects of rhAMG on f-actin labeling. Projection images of OCCM cells incubated in control and $100 \mu \mathrm{g} \cdot \mathrm{mL}^{-1} \mathrm{rhAMG}-\mathrm{containing}$ medium for $24 \mathrm{~h}$. Alexa 488-conjugated phalloidin probe was used for fluorescent labeling. Amplitude histograms of the images are shown in left panel. C control, rhAMG recombinant human amelogenin

\begin{tabular}{|lll|}
\hline $\begin{array}{l}\text { Table 1. } \\
\text { mouse }\end{array}$ & Primer sequences for mineralized tissue-associated genes for \\
\hline Primer & Forward & Reverse \\
\hline COL I & GCAACATTGGATTCCCTGGACC & GTTCACCCTTTTCTCCCTTGCC \\
BSP & GAGACGGCGATAGTTCC & AGTGCCGCTAACTCAA \\
OCN & TGAACAGACTCCGGCG & GATACCGTAGATGCGTTTG \\
OPN & TTTACAGCCTGCACCC & CTAGCAGTGACGGTCT \\
Runx2 & CTTCATTCGCCTCACAAAC & GTCACTGCGCTGAAGA \\
CAP & TCTGACGACTCTGCTTCACG & TTCAGGGCATGTGTGATGCT \\
ALP & ATTGCCCTGAAACTCCAAAACC & CCTCTGGTGGCATCTCGTTATC \\
GAPDH & ACCACAGTCCATGCCATCAC & TCCACCACCCTGTTGCTGTA \\
\hline
\end{tabular}

respectively, for $35-40$ cycles. The amplification profiles for BSP, OPN, and GAPDH used for the Stratagene MX3000P were 94/180; $94 / 45,52 / 45 ; 95 / 60,55 / 30$, and 95/30 [temperature $\left({ }^{\circ} \mathrm{C}\right) /$ time $(\mathrm{s})$ ], respectively, for $35-40$ cycles. The amplification profiles for CAP, ALP, and GAPDH used for the Stratagene MX3000P were 95/600; 95/15, 60/60; 95/60, 55/30, and 95/30 [temperature $\left({ }^{\circ} \mathrm{C}\right) /$ time (s)], respectively, for 35-40 cycles. Quantitative RT-PCR experiments were repeated three times.

\section{Mineralization assay}

The cells used in these experiments were between passages 19 and 21 . Cells were plated at $5 \times 10^{4}$ cells $/ \mathrm{cm}^{2}$ in 24 -well plates in DMEM containing $10 \%$ FBS for $24 \mathrm{~h}$ and exposed to the following factors: (a) $5 \%$ FBS $+\beta$-glycerophosphate $(10 \mathrm{mM})$, (b) $5 \%$ FBS + Mineralization Media [MM = ascorbic acid $(A A, 50 \mu \mathrm{g} / \mathrm{ml})$ and $\beta$ glycerophosphate (BGP, $10 \mathrm{mM})]$, (c) $5 \% \mathrm{FBS}+\mathrm{rhAMG}\left(0.1 \mathrm{ng} \cdot \mathrm{mL}^{-}\right.$ $\left.{ }^{1}\right)+\mathrm{MM}$, (d) $5 \% \mathrm{FBS}+\operatorname{rhAMG}\left(1 \mathrm{ng} \cdot \mathrm{mL}^{-1}\right)+\mathrm{MM}$, (e) $5 \% \mathrm{FBS}+$ rhAMG $\left(10 \mathrm{ng} \cdot \mathrm{mL}^{-1}\right)+\mathrm{MM}$, (f) $5 \% \mathrm{FBS}+\mathrm{rhAMG}\left(100 \mathrm{ng} \cdot \mathrm{mL}^{-1}\right)+$ MM, (g) $5 \% \mathrm{FBS}+\mathrm{rhAMG}\left(1000 \mathrm{ng} \cdot \mathrm{mL}^{-1}\right)+\mathrm{MM}$, (h) $5 \% \mathrm{FBS}+$ rhAMG $\left(10,000 \mathrm{ng} \cdot \mathrm{mL}^{-1}\right)+\mathrm{MM}$, and (i) $5 \% \quad \mathrm{FBS}+\mathrm{rhAMG}$ $\left(100,000 \mathrm{ng} \cdot \mathrm{mL}^{-1}\right)+\mathrm{MM}$. Mineralization of extracellular matrix was determined on day 8 by von Kossa staining. Briefly, cells were washed with PBS twice, fixed with $100 \%$ ethanol at $37^{\circ} \mathrm{C}$ for $1 \mathrm{~h}$ and washed in a descending alcohol series (90 to 50\%) to deionized water. Cells were treated with $5 \% \mathrm{AgNO}_{3}$ and incubated at $37^{\circ} \mathrm{C}$ in the dark for $15 \mathrm{~min}$ and washed with deionized water. Plates were exposed to fluorescent light for $20 \mathrm{~min}$, and photographs were obtained. ${ }^{59}$

\section{Immunostaining}

Cementoblasts were cultured on sterile coverslips for $48 \mathrm{~h}$ and fixed in $4 \%$ paraformaldehyde for $15 \mathrm{~min}$. Cells were washed in PBS und subsequently permeabilized with $0.05 \%$ Triton X-100 (Sigma) in PBS. The cells were washed and treated with $2 \%$ goat serum (Dako, Glostrup, Denmark) for $1 \mathrm{~h}$ at room temperature to reduce non-specific binding. The following primary antibodies were incubated for $4 \mathrm{~h}$ at $37^{\circ} \mathrm{C}$ : rabbit polyclonal anti-osteopontin (1:200; Abcam, Cambridge, USA), mouse monoclonal anti-collagen type I (1:200; Abcam), and mouse monoclonal anti-LAMP (1:500; Abcam). Peroxidase-conjugated anti-mouse or anti-rabbit EnVision $^{\circledR}$ (Dako) secondary antibodies were incubated for $30 \mathrm{~min}$ at room temperature. Diaminobenzidine (DAB) was used as the 
substrate. Cells were counterstained with haemalaunum. Primary and secondary antibodies were omitted in the negative controls.

\section{Confocal microscopy}

Cells were examined using a confocal laser scanning microscope (CFLSM) to observe the effects of rhAMG on cell adhesion. Cell viability, successful growth and proliferation in the new environment were determined. Cells were fluorescently labeled using lipophilic dye Dil as described in Hakki et al. ${ }^{62}$ OCCM-30 cells were seeded at an equal density $\left(30 \times 10^{3} / \mathrm{mL}\right)$ in cover glass bottom multi-well plates. Half of the wells were filled with control medium, and the other wells contained various rhAMG solutions (in control medium). Cells were fixed at $37^{\circ} \mathrm{C}$ in $5 \% \mathrm{CO}_{2}$ for $24 \mathrm{~h}$, and actin bundles were fluorescently labeled.

For imaging f-actin, cells were fixed in 4\% PFA, permeabilized, and blocked in $1 \%$ BSA. Samples were washed several times in PBS and incubated in an Alexa 488-labeled phalloidin solution for $30 \mathrm{~min}$ at room temperature $(5 \mathrm{U} / 200 \mu \mathrm{L}$ PBS). Samples were washed and mounted in an antifade solution. Plates were mounted on a confocal microscope, and cells were imaged under the same recording conditions. The $488 \mathrm{~nm}$ line of an argon ion laser was used for excitation, and emissions were collected using an LP $510 \mathrm{~nm}$ barrier filter. Z-stack images were acquired, and 3D projection images were constructed for analyses. For $\beta 1$ integrin imaging, cells were fixed, permeabilized and blocked in $1 \%$ goat serum. Samples were incubated in primary antibodies raised against human integrin in mouse for $12-24 \mathrm{~h}$ in PBS. Samples were washed several times in PBS and incubated with an Alexa 488-labeled goat anti-mouse secondary antibody. Samples were washed and mounted in an antifade solution. The $488 \mathrm{~nm}$ line of an argon ion laser was used for excitation, and emissions were collected through an LP $510 \mathrm{~nm}$ barrier filter. Z-stack images were acquired, and 3D images were constructed for topographical analyses of cell growth and quantification. Recordings were analyzed to observe changes in fluorescent labeling between test groups and the control group. Amplitude histograms were constructed from the projection images. The first lowest intensity levels were ignored to eliminate background labeling.

Statistical analysis

Proliferation and RT-PCR results were analyzed using one-way analysis of variance (ANOVA) and Tukey-Kramer multiple comparison tests. Data are presented as the means \pm standard deviation.

\section{ACKNOWLEDGEMENTS}

This study was supported by TÜBITAK SBAG108S265 (Turkey) and BMBF TUR08/09 (Germany). We thank Johan Svensson and Leif Bülow for rhAMG production and characterization studies from Department of Pure and Applied Biochemistry, Center for Chemistry and Chemical Engineering Lund University, Lund, Sweden for rhAMG synthesis.

\section{ADDITIONAL INFORMATION}

Competing interests: The authors declare no competing interests.

\section{REFERENCES}

1. Bosshardt, D. D. Biological mediators and periodontal regeneration: a review of enamel matrix protein at the cellular and molecular level. J. Clin. Periodontol. 35 (Suppl 8), 87-105 (2008).

2. Lyngstadaas, S. P. et al. Enamel matrix proteins; old molecules for new applications. Orthod. Craniofac. Res. 12, 1-11 (2009).

3. Hakki, S. S., Berry, J. E. \& Somerman, M. J. The effect of enamel matrix protein derivative on follicle cells in vitro. J. Periodontol. 72, 679-687 (2001).

4. Grandin, H. M., Gemperli-Graf, A. \& Dard, M. Enamel matrix derivative: a review of cellular effects in vitro and a model of molecular arrangement and functioning. Tissue Eng. Part B 18, 181-202 (2012).
5. Hatakeyama, J. et al. Amelogenin-mediated regulation of osteoclastogenesis, and periodontal cell proliferation and migration. J. Dent. Res. 85, 144-149 (2006).

6. Zeichner-David, M. et al. Amelogenin and ameloblastin show growth-factor like activity in periodontal ligament cells. Eur. J. Oral Sci. 114, 244-253 (2006). Suppl 1.

7. Miron, R. J. et al. Twenty years of enamel matrix derivative: the past, the present and the future. J. Clin. Periodontol. 43, 668-683 (2016). b.

8. Giannobile, W. V. \& Somerman, M. J. Growth and amelogenin-like factors in periodontal wound healing. A systematic review. Ann. Periodontol. 8, 193-204 (2003).

9. Sculean, A. et al. The application of an enamel matrix protein derivative (Emdogain) in regenerative periodontal therapy: a review. Med. Princ. Pract. 16, 167-180 (2007).

10. Esposito, M. et al. Enamel matrix derivative (Emdogain $\left.{ }^{\circledR}\right)$ for periodontal tissue regeneration in intrabony defects. A Cochrane systematic review. Eur. J. Oral Implantol. 2, 247-266 (2009).

11. Rathe, F. et al. The effect of enamel matrix derivative (Emdogain ${ }^{\circledR}$ ) on bone formation: a systematic review. Tissue Eng: Part B 15, 215-224 (2009).

12. Koop, R., Merheb, J. \& Quirynen, M. Periodontal regeneration with enamel matrix derivative in reconstructive periodontal therapy: a systematic review. J. Periodontol. 83, 707-720 (2012).

13. Schmidlin, P. R. Regenerative treatment of a cemental tear using enamel matrix derivatives:a ten-year follow-up. Open Dent. J. 6, 148-152 (2012).

14. Matarosso, $M$. et al. Enamel matrix deriavtive and bone grafts for periodontal regeneration of intrabony defects. A systematic review and meta-analysis. Clin. Oral Invest 19, 1581-1593 (2015).

15. Al-Hezaimi, K., Al-Askar, M. \& Al-Rasheed, A. Characteristics of newly formed cementum following emdogain application. Int. J. Oral Sci. 3, 21-26 (2011).

16. Bosshardt, D. D. et al Pattern of mineralization after regenerative periodontal therapy with enamel matrix proteins. Eur. J. Oral. Sci. 114(Suppl 1), 225-231 (2006).

17. Amin, H. D. et al. Differential effect of amelogenin peptides on osteogenic differentiation in vitro: identification of possible new drugs for bone repair and regeneration. Tissue Eng. Part A 18, 1193-1202 (2012).

18. Fawzy El-Sayed, K. M. et al. Effect of Emdogain enamel matrix derivative and BMP-2 on the gene expression and mineralized nodule formation of alveolar bone proper-derived stem/progenitor cells. J. Cranio-Maxillo-Fac. Surg. 42, 568-576 (2013).

19. Wang, Y., Zhao, Y. \& Ge, L. Effects of the enamel matrix derivative on the proliferation and odontogenic differentiation of human dental pulp cells. J. Dent. 42, 53-59 (2014).

20. Miron, R. J. et al. Gene array of primary human osteoblasts exposed to enamel matrix derivative in combination with a natural bone material. Clin. Oral Invest 17, 405-410 (2013).

21. Miron, R. J. et al. Effect of enamel matrix derivative liquid on osteoblast and periodontal ligament cell proliferation and differentiation. J. Periodontol. 87, 91-99 (2016).

22. Frasheri, l. et al. Full-length amelogenin influences the differentiation of human dental pulp stem cells. Stem Cell Res. Ther. 7, 10 (2016).

23. Wang, Z. et al. In vitro studies on human periodontal ligament stem cell sheets enhanced by enamel matrix derivative. Colloids Surf. B Biointerfaces 141, 102-111 (2016).

24. Swanson, E. C. et al. Amelogenins regulate expression of genes associated with cementoblasts in vitro. Eur. J. Oral Sci. 114(Suppl 1), 239-243 (2006).

25. Ruan, Q. \& Moradian-Oldak, J. Amelogenin and enamel biomimetics. J. Mater. Chem. B 3, 3112-3129 (2015).

26. Bosshardt, D. D. et al. Effects of enamel matrix proteins on tissue formation along the roots of human teeth. J. Periodontal. Res. 40, 158-167 (2005).

27. Tompkins, K., George, A. \& Veis, A. Characterization of a mouse amelogenin [A-4]/ M59 cell surface receptor. Bone 38, 172-180 (2006).

28. Shapiro, J. L. et al. Cellular uptake of amelogenin, and its localization to CD63, and lamp1-positive vesicles. Cell Mol. Life. Sci. 64, 244-256 (2007).

29. Gungormus, M. et al. Cementomimetics-constructing a cementum-like biomineralized microlayer via amelogenin-derived peptides. Int. J. Oral Sci. 4, 69-77 (2012).

30. Simmer, J. P. et al. Isolation and characterization of a mouse amelogenin expressed in Escherichia coli. Calcif. Tissue Int. 54, 312-319 (1994).

31. Deutsch, D. et al. Regeneration of the periodontal tissues in vivo using the recombinant human amelogenin protein. J. Dent. Res. 82, 292 (2003).

32. Taylor, A. L. et al. High yield of biologically active recombinant human amelogenin using the baculovirus expression system. Protein Expr. Purif. 45, 43-53 (2006).

33. Haze, A. et al. Regeneration of bone and periodontal ligament induced by recombinant amelogenin after periodontitis. J. Cell Mol. Med. 13, 1110-1124 (2009). 
34. Li, W. et al. X-linked amelogenesis imperfecta may result from decreased formation of tyrosine rich amelogenin peptide (TRAP). Arch. Oral Biol. 48, 177-183 (2003).

35. Svensson, J. et al. Histidine tag fusion increases expression levels of active recombinant amelogenin in Escherichia coli. Protein Expr. Purif. 48, 134-141 (2006).

36. Mounir, M. M., Matar, M. A. \& Snead, M. L. Recombinant amelogenin protein induces apical closure and pulp regeneration in open-apex, nonvital permanent canine teeth. J. Endod. 42, 402-412 (2016).

37. Bosshardt, D. D. Are cementoblasts a subpopulation of osteoblasts or a unique phenotype? J. Dent. Res. 84, 390-406 (2005).

38. D'Errico, J. A. et al. Employing a transgenic animal model to obtain cementoblasts in vitro. J. Periodontol. 71, 63-72 (2000).

39. Tokiyasu, Y. et al. Enamel factors regulate expression of genes associated with cementoblasts. Periodontolgy 71, 1829-1839 (2000).

40. Viswanathan, H. L. et al. Amelogenin: a potential regulator of cementumassociated genes. J. Periodontol. 74, 1423-1431 (2003).

41. Boabaid, F. et al. Leucine-rich amelogenin peptide: a candidate signaling molecule during cementogenesis. J. Periodontol. 75, 1126-1136 (2004).

42. Kunimatsu, R. et al. Amelogenin enhances the proliferation of cementoblast lineage cells. J. Periodontol. 82, 1632-1638 (2011).

43. Yoshimi, Y. et al. Effects of C-terminal amelogenin peptide on proliferation of human cementoblast lineage cells. J. Periodontol. 87, 820-827 (2016).

44. Tanimoto, K. et al. Differential effects of amelogenin on mineralization of cementoblasts and periodontal ligament cells. J. Periodontol. 83, 672-679 (2012).

45. Veis, A. et al. Specific amelogenin gene splice products have signaling effects on cells in culture and in implants in vivo. J. Biol. Chem. 275, 41263-41272 (2000).

46. Warotayanont, R. et al. Leucine-rich amelogenin peptide induces osteogenesis in mouse embryonic stem cells. Biochem. Biophys. Res. Commun. 367, 1-6 (2008).

47. Warotayanont, R. et al. Leucine-rich amelogenin peptide induces osteogenesis by activation of the wnt pathway. Biochem. Biophys. Res. Commun. 387, 558-563 (2009).

48. Johnson, D. L. et al. Cellular effects of enamel matrix derivative are associated with different molecular weight fractions following separation by size-exclusion chromatography. J. Periodontol. 80, 648-656 (2009).

49. Jue, S. S. et al. The effects of enamel matrix derivative on the proliferation and differentiation of human mesenchymal stem cells. Clin. Oral Implants Res. 21, 741-746 (2010).

50. Jingchao, H. et al. Human amelogenin up-regulates osteogenic gene expression in human bone marrow stroma cells. Biochem Biophys. Res. Comm. 408, 437-441 (2011).

51. Izumikawa, M. et al. Effects of amelogenin on proliferation, differentiation, and mineralization of rat bone marrow mesenchymal stem cells in vitro. Sci. World J. 2012, 879731 (2012)

52. Miron, R. J. et al. Gene array of primary human osteoblasts exposed to enamel matrix derivative in combination with natural bone mineral. Clin. Oral Invest. 17, 405-410 (2013).
53. Vrtačnik, P., Marc, J. \& Ostanek, B. Epigenetic mechanisms in bone. Clin. Chem. Lab. Med. 52, 589-608 (2014).

54. Arzate, H., Zeichner-David, M. \& Mercado-Celis, G. Cementum proteins: role in cementogenesis, biomineralization, periodontium formation and regeneration. Periodontology 67, 211-233 (2015).

55. Zhang, $H$. et al. Full length amelogenin binds to cell surface LAMP-1 on tooth root/periodontium associated cells. Arch. Oral Biol. 55, 417-425 (2010).

56. Almqvist, S. et al. Amelogenin is phagocytized and induves changes in integrin configuration, gene expression and prolferation of cultured normal human dermal fibroblasts. J. Mater. Sci. Mater. Med. 21, 947-954 (2010).

57. Gassmann, G. et al. Influence of enamel matrix derivative on primary CD4+ Thelper lymphocyte migration, CD25 activation, and apoptosis. J. Periodontol. 80, 1524-1533 (2009)

58. Svensson Bonde, J. \& Bulow, L. One-step purification of recombinant human amelogenin and use of amelogenin as a fusion partner. PLoS ONE 7, e33269 (2012).

59. Hakki, S. S. et al. Bone morphogenetic protein-7 enhances cementoblast function in vitro. J. Periodontol. 81, 1663-1674 (2010).

60. Butler, S. J., Bülow, L. \& Bonde, J. Functionalization of recombinant amelogenin nanospheres allows their binding to cellulose materials. Biotechnol. J. 11, 1343-1351 (2016).

61. Chen, D. et al. Osteoblastic cell lines derived from a transgenic mouse containing the osteocalcin promoter driving SV T-antigen. Mol. Cell Differ. 3, 193-212 (1995).

62. Hakki SS, Korkusuz P, Purali N, Bozkurt B, Kus M, Duran I. Attachment, proliferation and collagen type I mRNA expression of human gingival fibroblasts on different biodegradable membranes. Connect Tissue Res 54, 260-226 (2013)

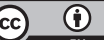

Open Access This article is licensed under a Creative Commons Attribution 4.0 International License, which permits use, sharing, adaptation, distribution and reproduction in any medium or format, as long as you give appropriate credit to the original author(s) and the source, provide a link to the Creative Commons license, and indicate if changes were made. The images or other third party material in this article are included in the article's Creative Commons license, unless indicated otherwise in a credit line to the material. If material is not included in the article's Creative Commons license and your intended use is not permitted by statutory regulation or exceeds the permitted use, you will need to obtain permission directly from the copyright holder. To view a copy of this license, visit http://creativecommons. org/licenses/by/4.0/.

(c) The Author(s) 2018 